\title{
NCKIPSD Gene
}

National Cancer Institute

\section{Source}

National Cancer Institute. NCKIPSD Gene. NCI Thesaurus. Code C97433.

This gene plays a role in stress fiber formation. 